\title{
Interpretant in the Film of Kucumbu Tubuh Indahku by Garin Nugroho
}

\author{
Puri Kurniasih $^{1}$, Bambang Sunarto ${ }^{2}$, Tommy Christomy ${ }^{3}$ \\ \{purikurniasih@gmail.com ${ }^{1}$, benarto@hotmail.com ${ }^{2}$, t.christomy@gmail.com ${ }^{3}$ \} \\ Universitas Indraprasta PGRI, Jakarta, Indonesia ${ }^{1}$, Institut Seni Indonesia (ISI) Surakarta, Indonesia ${ }^{2}$, \\ Universitas Indonesia ${ }^{3}$
}

\begin{abstract}
Kucumbu Tubuh Indahku (Memories of My Body) was one of Garin Nugroho's films, aired in 2019. This film was controversial; on the one hand it received rejection, but on the other hand was rewarded. The purpose of this study was to examine the title Kucumbu Tubuh Indahku from the semiotic perspective of Charles Sanders Peirce. This study used an analytical interpretation method with interpretant trichotomy-rheme, dicent, and argument - as the tool of analysis. The result of this study indicated that there were two different interpretations of the title, namely poetic and erotic impressions. People who were pro with the film got the impression that the title was poetic, while those who were against it considered the title to be erotic. This study concluded that the pros and cons occur in society because the title had multiple interpretations or was at the rheme level.
\end{abstract}

Keywords: movie's title, controversy, semiotics, Charles Sanders Peirce.

\section{Interpretant dalam Film Kucumbu Tubuh Indahku Karya Garin Nugroho}

\begin{abstract}
Abstrak. Kuсumbu Tubuh Indahku adalah salah satu film karya Garin Nugroho yang tayang pada tahun 2019. Film ini menuai kontroversi; di satu sisi mendapatkan penolakan, namun di sisi lain diganjar penghargaan. Tujuan dari tulisan ini adalah untuk menelaah judul Kuсumbu Tubuh Indahku dari perspektif semiotika Charles Sanders Peirce. Penelitian ini menggunakan metode interpretasi analisis dengan trikotomi interpretant—rheme, dicent, dan argument—sebagai pisau analisis. Hasil penelitian ini menunjukkan adanya dua interpretasi yang berbeda terhadap judul tersebut, yaitu kesan puitis dan erotis. Kalangan masyarakat yang pro menangkap kesan bahwa judul tersebut adalah judul yang puitis, sementara kalangan masyarakat yang kontra menganggap judul tersebut erotis. Tulisan ini menyimpulkan bahwa pro dan kontra terjadi di masyarakat karena judul tersebut memiliki tanda yang multitafsir atau berada pada tingkatan rheme.
\end{abstract}

Kata kunci: judul film, kontroversi, semiotika, Charles Sanders Perice.

\section{Pendahuluan}

"Kucumbu Tubuh Indahku" (Memories of My Body) adalah salah satu film bergenre drama yang bercerita tentang penari Lengger Lanang, disutradarai dan ditulis oleh Garin 
Nugroho, diproduseri oleh Ifa Isfansyah, dan diproduksi oleh Fourcolours Films dengan durasi 107 menit. Hadir di bioskop Indonesia pada tanggal 18 April 2019, secara keseluruhan film tentang konflik identitas gender ini sudah selesai proses produksinya pada tahun 2018 [1].

Film "Kucumbu Tubuh Indahku" dapat disebut sebagai salah satu film yang kontroversial di Indonesia karena mendatangkan pro dan kontra di masyarakat. Kebanyakan khalayak yang berasal dari komunitas film sangat mendukung karya terbaru Garin Nugroho ini, bahkan film ini mendapatkan banyak penghargaan dari festival-festival film di luar negeri dan menjadi film terbaik FFI 2019. Pihak yang pro berasal dari para sineas, komunitas film, dan sebagian masyarakat yang menonton film tersebut. Diakui Garin, "Kucumbu Tubuh Indahku" adalah film dengan tema yang sensitif. Film ini juga menyinggung soal LGBT. Bahkan ketika tayang di Indonesia, "Kucumbu Tubuh Indahku" diprotes karena isu sensitifnya. Saat penayangannya, banyak yang mendesak agar film ini segera diturunkan. Tapi, kacamata seni dunia perfilman justru menilai lain. Walaupun diprotes di negeri sendiri, film ini malah meraih penghargaan di luar negeri [2]. Pihak yang kontra terhadap film "Kucumbu Tubuh Indahku" rata-rata adalah elemen masyarakat yang justru belum menonton film ini [3] [4] [5] [6]. Bahkan hingga ada petisi dan surat edaran resmi untuk menolak dan melarangnya. Dengan demikian, apabila yang kontra belum menonton film ini, kemungkinan penolakan mereka adalah atas dasar judul, poster, cuplikan film (trailer), sinopsis, review, atau petisi.

Berangkat dari situasi di atas, dengan menggunakan perspektif semiotika Charles Sanders Peirce, tulisan ini akan mencoba mendiskusikan kontroversi penayangan film "Kucumbu Tubuh Indahku". Berbagai penelitian terdahulu telah pula menggunakan perspektif serupa untuk mengkaji karya film. Skripsi berjudul "Analisis Semiotik Film Cin(t)a Karya Sammaria Simanjuntak" [7] menganalisis simbol yang terkandung dalam dialog, pengambilan gambar, dan gerak pemain dengan teori semiotika Peirce. Berdasarkan konsep-konsep ikon, indeks, dan simbol sebagai pisau analisisnya, Fajriah menyimpulkan bahwa cinta terbagi dua, yaitu cinta kepada Tuhan dan cinta kepada sesama makhluk. Artikel berjudul "Analisis Semiotika pada Film Laskar Pelangi" [8] menggunakan pendekatan estetika Peirce untuk menelaah fenomena yang menjadi ikon pada film Laskar Pelangi. Hasil penelitiannya mengungkap pemaknaan ikon-ikon yang terdapat pada film Laskar Pelangi. Kedua penelitian tersebut menggunakan teori trikotomi Peirce yang kedua, yaitu klasifikasi tanda-tanda yang berkaitan dengan hubungan antara representamen dan objek. Ketiga anggota trikotomi ini adalah ikon (icon, firstness), indeks (index, secondness), dan simbol (symbol, thirdness). Berbeda dengan keduanya, penelitian ini akan fokus pada trikotomi ketiga, yaitu menurut sifat penafsir, tanda bisa berupa rheme, dicent, dan argument.

Artikel berjudul "Analisis Representasi Maskulinitas pada Tokoh Juno Film "Kucumbu Tubuh Indahku" [9] telah terlebih dahulu membahas tentang film "Kucumbu Tubuh Indahku", namun fokus analisisnya ada pada tokoh utama film, yaitu Juno. Penelitian tersebut menyatakan bahwa film selalu memengaruhi masyarakat melalui isi pesan yang disampaikan. Pesan yang terkandung dalam film akan membentuk pola pikir dan perilaku penonton. Pada film "Kucumbu Tubuh Indahku", Juno digambarkan sebagai pria yang feminin dan tidak membawa pesan maskulinitas. Penelitian ini menjadi pijakan pada penulisan artikel ini, bahwa ternyata pesan bahkan dapat disampaikan hanya melalui sebuah judul film. Pola pikir dan perilaku penonton dapat terbentuk bahkan sedari membaca judul film.

Salah satu hasil penelitian yang membahas judul film adalah artikel berjudul "Semantik Ragam Makna pada Judul Film Azab di Indosiar" [10]. Artikel tersebut membahas maknamakna semantik yang terkandung pada judul film azab di stasiun televisi Indosiar. Hasil penelitian tersebut memperkuat studi pada artikel ini, bahwa Garin Nugroho menggunakan variasi ragam bahasa pada judul filmnya yang kemudian menjadi kontroversi. Namun, 
penelitian ini bukan membongkar semantik pada judul film "Kucumbu Tubuh Indahku", melainkan membacanya secara semiotik.

Jadi, penelitian ini akan fokus pada salah satu kemungkinan penyebab kontra, yaitu judul film "Kucumbu Tubuh Indahku". Penelitian ini akan menjawab pertanyaan mengapa judul film "Kucumbu Tubuh Indahku" mendatangkan sikap kontra di kalangan masyarakat yang belum menonton film tersebut? Penelitian ini akan menjawab pertanyaan tersebut dengan menggunakan teori semiotika Peirce.

\section{Metode}

Penelitian ini menggunakan pendekatan kualitatif dengan metode interpretasi analisis dari teori semiotika Charles Sanders Peirce. Teori semiotika Peirce dapat disebut sebagai "teori besar" (grand theory) karena sifatnya yang menyeluruh. Dalam teori ini, deskripsi struktural berasal dari semua penanda, yaitu dengan mengidentifikasi partikel dasar dari tanda dan menggabungkan kembali komponennya dalam struktural tunggal [8].

Hal esensial dalam semiotika Peirce adalah sistem kategorinya. Peirce mengembangkan fenomenologi berdasarkan tiga kategori universal yang disebut kepertamaan (firstness), kekeduaan (secondness), dan keketigaan (thirdness). Kepertamaan adalah cara menjadi apa adanya, secara positif dan tanpa mengacu pada hal lain. Ini adalah kategori perasaan yang tidak direfleksikan, potensi belaka, kebebasan, kesegeraan, kualitas, dan kemandirian yang tidak dibedakan. Kekeduaan adalah melibatkan hubungan yang pertama dengan yang kedua. Ini adalah kategori perbandingan, faktisitas, tindakan, realitas, dan pengalaman dalam ruang dan waktu - dalam bentuk fakta-fakta, relasi, paksaan, efek, ketergantungan, kemandirian, negasi, kejadian, realitas, hasil. Keketigaan membawa yang kedua dalam hubungannya dengan yang ketiga; merupakan kategori mediasi, kebiasaan, ingatan, kontinuitas, sintesis, komunikasi (semiosis), representasi, dan tanda-tanda [11].

Tanda bagi Peirce merupakan proses triadik yang disebut dengan istilah semiosis. Tanda berpartisipasi pada tiga kategori: representamen, objek, dan interpretant [11]. Representamen terbagi atas qualisign, sinsign, dan legisign; objek terbagi atas icon, index, dan symbol; interpretant terbagi atas rheme, dicent, dan argument. Penelitian-penelitian sebelumnya banyak yang menggunakan trikotomi kedua [7] [8], sementara penelitian ini berfokus pada kategori ketiga, yaitu interpretant.

Analisis dalam tulisan ini dilakukan melalui beberapa tahap. Tahap pertama, mengidentifikasi "Kucumbu Tubuh Indahku" pada tanda triadik: Representamen (R), Interpretant (I), dan Object (O). Tahap kedua, fokus pada kategori interpretant, yaitu menganalisis interpretasi antara Garin Nugroho $(\mathrm{GN})$ dan masyarakat yang pro dengan masyarakat yang kontra. Tahap ketiga, menentukan hasil analisis interpretasi judul "Kucumbu Tubuh Indahku" pada kategori interpretant, apakah judul tersebut berupa rheme, dicent, atau argument.

\section{Hasil dan Pembahasan}

Representamen adalah istilah Peirce untuk "objek yang bisa dilihat" yang berfungsi sebagai tanda. Pada trikotomi pertama, dari sudut pandang representamen, Peirce membagi tanda menjadi qualisigns (termasuk dalam kategori firstness), sinsigns atau token 
(secondness), dan legisigns atau types (thirdness). Menurutnya, "tanda itu sendiri adalah kualitas belaka, adalah keberadaan yang sebenarnya, atau merupakan hukum umum." Trikotomi kedua mengklasifikasikan tanda-tanda yang berkaitan dengan hubungan antara representamen dan objek. Peirce menyebut trikotomi ini sebagai "pembagian tanda yang paling fundamental." Ketiga anggota trikotomi ini adalah icon (firstness), index (secondness), dan symbol (thirdness). Trikotomi ketiga adalah menurut sifat penafsir, tanda bisa berupa rheme, dicent, dan argument. Trikotomi ini "sesuai dengan pembagian lama (logika), istilah, proposisi, dan argumen, dimodifikasi sehingga dapat diterapkan pada tanda-tanda secara umum." Sebuah term "hanya nama kelas atau nama diri," sedangkan rheme adalah "tanda apapun (bukan soal benar atau salah), hampir semua kata kecuali 'ya' dan 'tidak'." Rheme adalah "tanda sederhana atau pengganti." Dicent (atau dicisign) adalah tanda keberadaan aktual, seperti proposisi, merupakan tanda yang informatif, tetapi tidak menegaskan. Cara mengecek dicent adalah dengan mengecek benar atau salah. Argument adalah "tanda hukum," yaitu peralihan dari semua premis ke kesimpulan, sehingga cenderung pada kebenaran. Sementara dicent hanya menegaskan keberadaan suatu objek, argument membuktikan kebenarannya [11].

\subsection{Kucumbu Tubuh Indahku pada Tanda Triadik Peirce}

Representamen yang akan dibahas pada penelitian ini adalah judul "Kucumbu Tubuh Indahku." Ini adalah "objek yang bisa dilihat" dengan mudah bahkan bagi yang belum pernah menonton film tersebut. "Kucumbu Tubuh Indahku" merupakan bentuk dari tanda (the form of the sign) itu sendiri. Selanjutnya, makna yang muncul dari tanda tersebut (the sense made of the sign) adalah interpretasi dari masyarakat yang pro dan yang kontra, yang disebut dengan interpretant. Adapun yang dirujuk oleh tanda tersebut (what the sign stands for) adalah film "Kucumbu Tubuh Indahku", yang merupakan referent atau objeknya. Dengan demikian, dapat dikatakan bahwa judul "Kucumbu Tubuh Indahku" adalah "yang mewakili," sementara film "Kucumbu Tubuh Indahku" adalah "yang diwakili," dan di antara keduanya terdapat interpretasi. Berikut gambar diagram untuk mempermudah pemahaman atas penjabaran tersebut:

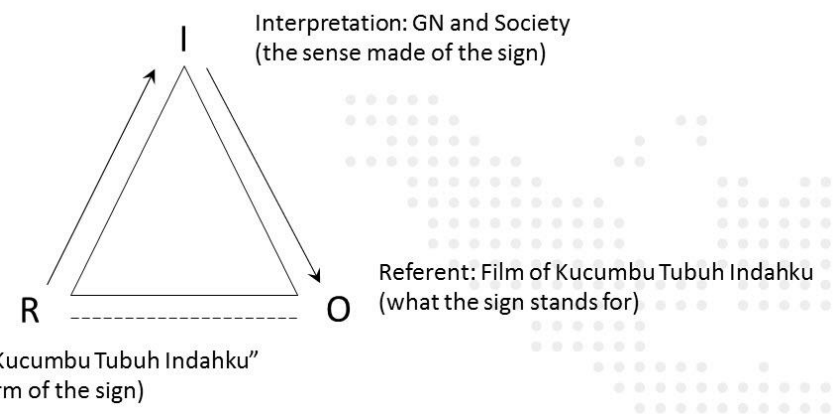

(the form of the sign)

Gambar 1. Kucumbu Tubuh Indahku pada Tanda Triadik Peirce Sumber: Dokumentasi Penulis, 28 Oktober 2020.

Berdasarkan Gambar 1, tidak ada persoalan pada representamen (judul film) maupun objek (film). Persoalan justru muncul pada interpretant (interpretasi tentang judul) sehingga memiliki imbas pada penayangan film tersebut. Representamen yang sama memunculkan interpretant yang berbeda, sehingga menimbulkan dampak yang berbeda pada objek yang sama. 


\subsection{Kucumbu Tubuh Indahku: Puitis atau Erotis?}

Interpretant adalah istilah Peirce untuk arti sebuah tanda. Kadang-kadang, Peirce mendefinisikannya sebagai "signifikansi," "signifikasi," atau "interpretasi." Interpretasi yang muncul dari judul "Kucumbu Tubuh Indahku" terpolarisasi menjadi dua kubu, yaitu interpretasi dari GN dan masyarakat yang pro, dengan interpretasi dari masyarakat yang kontra terhadap penayangan film tersebut.

Bagi GN dan masyarakat yang pro, judul "Kucumbu Tubuh Indahku" adalah judul yang puitis. Menurut Agus Budi Purnomo, puitis adalah sesuatu hal yang bersifat puisi yang digambarkan menggunakan irama, matra, dan rima tertentu. Sifat atau gaya ini memiliki irama, matra, dan rima sehingga terlihat dan terdengar indah, lalu dapat menyentuh psikologi manusia karena diucapkan dengan tekanan suara tertentu sehingga menimbulkan dan membentuk suasana emosional karena di dalamnya mengandung makna [12]. Kemungkinankemungkinan judul bisa saja menjadi "Kucumbu Tubuhku yang Indah" atau "Aku mencumbu Tubuh Aku yang Indah." Atau bahkan mengikuti terjemahan harfiah dari judul asingnya, "Memories of My Body," yakni "Memori Tubuhku." Namun, di antara kemungkinankemungkinan tersebut, tidak ada yang memiliki irama, matra, dan rima seperti "Kucumbu Tubuh Indahku." Dengan demikian, judul ini memang sudah dibuat menjadi puitis.

Adapun bagi masyarakat yang kontra, judul "Kucumbu Tubuh Indahku" adalah judul yang erotis. Pada dasarnya, erotisme berkaitan erat dengan dan bahkan didasari oleh libido yang dalam perkembangan selanjutnya teraktualisasikan dalam keinginan seksual [13]. Respons kontra muncul karena judul tersebut mengarah pada "keinginan seksual." Terlebih erotisme pada judul tersebut divisualisasikan dalam bentuk poster bergambar laki-laki yang bersolek seperti perempuan yang berdasarkan level realitas semiotika John Fiske-kode tampilan, kode pakaian, kode gestur, kode ekspresi, dan kode perilaku-menunjukkan representasi feminin pada tokoh Juno [9]. Dengan demikian, wajar kiranya jika sebelum ditonton, muncul asumsi bahwa film yang berjudul erotis ini memang tentang LGBT.

Erotisme dapat berkaitan erat dengan pornografi, yang didefinisikan sebagai (1) penggambaran tingkah laku secara erotis dengan lukisan atau tulisan untuk membangkitkan nafsu birahi; (2) bahan bacaan yang dengan sengaja dan semata-mata dirancang untuk membangkitkan nafsu birahi dan seks. Erotisme dan libido merupakan dasar untuk menggambarkan sesuatu secara lebih luas (misalnya konsep cinta, perbedaan antarjenis, atau masalah yang timbul dalam tradisi interaksi sosial), sedangkan pornografi menonjolkan penggambaran secara sengaja tingkah laku seksual dengan tujuan membangkitkan nafsu seksual. Dapat disimpulkan bahwa makna erotisme lebih mengarah pada penggambaran perilaku, keadaan, atau suasana yang didasari oleh libido dalam arti keinginan seksual, sedangkan pornografi lebih cenderung pada tindak seksual yang ditonjolkan untuk membangkitkan nafsu birahi. Erotisme tidak memiliki makna dasar cabul, melainkan menggambarkan perilaku, keadaan atau suasana berdasarkan libido atau seks. Sebaliknya, pornografi mempunyai makna dasar cabul. Dalam pornografi terdapat erotisme, tetapi tidak semua yang erotis itu pornografis [13]. Memang erotisme berkaitan dengan pornografi, tetapi erotisme bukanlah pornografi. Apabila judul dianggap erotis, tidak dapat disalahkan. Namun ketika film dianggap pornografi, ini memiliki konsekuensi perdebatan panjang tentang adegan pada film yang sudah lulus sensor tersebut.

\subsection{Rheme pada Kucumbu Tubuh Indahku}

Film mampu menjadi sebuah pernyataan budaya yang ingin digambarkan oleh pembuat film [9]. Garin Nugroho adalah seorang sutradara yang memiliki karakter idealis yang bernusantara. Bentuk pragmatis yang terdapat pada film "Kucumbu Tubuh Indahku" adalah 
upaya mengangkat kearifan lokal Indonesia [14]. Perbedaan interpretasi antara masyarakat yang pro dan yang kontra menunjukkan adanya perbedaan ragam bahasa, sehingga memaknai bahasa dengan berbeda pula.

Ragam bahasa adalah variasi yang ada di dalam sebuah bahasa yang sedang digunakan. Adanya ragam bahasa juga bisa dilihat pada media perfilman, salah satunya pada judul film. Faktor pendorong adanya ragam bahasa dalam judul film adalah kebutuhan akan kata yang baru, perubahan lingkungan, psikologis, sosial, dan kesejarahan [10]. Ragam bahasa yang puitis (atau justru dianggap erotis) pada film "Kucumbu Tubuh Indahku" berhasil mendatangkan pro dan kontra di masyarakat. Dengan demikian, judul tersebut memungkinkan adanya perbincangan mengenai film tersebut. Terlepas apakah diterima atau ditolak, film "Kucumbu Tubuh Indahku" berhasil mengada di tengah-tengah masyarakat, menjadi perbincangan, dan membuka ruang diskusi dan adu ilmu antar-ahli. Hal ini dapat mengedukasi masyarakat.

Trikotomi interpretant muncul dalam hubungan antara pikiran dengan jenis objeknya, yaitu antara pikiran masyarakat yang pro dan yang kontra dengan judul "Kucumbu Tubuh Indahku." Mengacu pada trikotomi rheme, dicent, dan argument, judul ini tidak bersifat informatif karena tidak melahirkan satu pemahaman yang sama, juga bukan sebuah kaidah atau aturan atau hukum. Dengan demikian, judul "Kucumbu Tubuh Indahku" bukan berbentuk dicent ataupun argument, melainkan rheme karena memberikan kemungkinan multitafsir. Lebih jauh, hal ini dapat dilihat dari pemaknaan atas kata "cumbu" dan "tubuh indah" pada judul tersebut.

Berdasarkan KBBI, cumbu memiliki arti (1) kata-kata manis yang dipakai untuk membujuk (waktu berkasih-kasihan dan sebagainya), (2) senda gurau; lelucon (kelakar, olokolok, dan sebagainya) [15]. Adapun jika kata tersebut digunakan sebagai kata kunci (query) dalam pencarian gambar (image) di Google, maka akan memunculkan hasil pencarian berupa gambar-gambar berciuman. Dapat ditarik kesimpulan, bahwa cumbu adalah aktivitas yang berhubungan dengan kedekatan fisik. Dalam hal ini, mencumbu tubuh sendiri dapat memiliki arti berusaha dekat dengan tubuh sendiri dengan membujuk dan bersenda gurau dengan diri sendiri. Namun, bisa jadi ada persepsi yang berbeda, bahwa mencumbu tubuh sendiri dapat pula memiliki arti menciumi diri sendiri, seperti autoseksual. Perbedaan pemahaman pada makna cumbu dapat melahirkan perbedaan persepsi terhadap judul "Kucumbu Tubuh Indahku."

Selanjutnya, pada karya-karya video maupun film eksperimental pada umumnya, terdapat kecenderungan pemujaan terhadap keindahan tubuh perempuan dengan menampilkan sisi-sisi erotisme tubuh. Konstruksi erotisme muncul dalam berbagai bentuk dan versi estetika yang berbeda-beda. Namun, eksplorasi keindahan tubuh tersebut pada umumnya digambarkan melalui penonjolan unsur-unsur fisik perempuan yang mendominasi [16]. Berbeda halnya pada "Kucumbu Tubuh Indahku", di mana konsep tubuh indah diletakkan bukan pada tubuh perempuan. Konsep indah pada film ini justru ada pada penari Lengger Lanang dari Banyumas; seorang laki-laki yang menarikan tarian perempuan dan berdandan seperti perempuan. Satu tubuh berisi kualitas maskulin sekaligus feminin merupakan bentuk kesempurnaan [17]. Tubuh yang indah pada film "Kucumbu Tubuh Indahku", dengan demikian, ada pada bentuk kesempurnaan tersebut, yaitu perpaduan feminin dan maskulin dalam satu tubuh sebagai bentuk analogi. Namun, konsep laki-laki yang berdandan dan melakukan tarian perempuan bisa juga dipahami sebagai ekspresi LGBT, di mana bagi kalangan mayoritas di Indonesia, LGBT masih dianggap bukan sebagai bentuk keindahan. Bagi mayoritas, yang umumnya memegang orientasi heteroseksual, indah adalah ketika perempuan itu feminin dan laki-laki itu maskulin, sehingga laki-laki yang feminin tidak dapat 
disebut indah. Dengan demikian, perbedaan pandangan antara konsep maskulin dan feminin dapat melahirkan persepsi yang berbeda pula tentang konsep tubuh indah.

\section{Simpulan}

Pengertian dasar rheme adalah tanda yang dapat diinterpretasikan sebagai representasi dari suatu kemungkinan denotatum. Kata-kata yang belum memiliki konteks merupakan rheme karena masih bisa ditafsirkan dengan berbagai konteks. Menurut Aart van Zoest, tanda merupakan rheme bila dapat diinterpretasikan sebagai representasi dari suatu kemungkinan denotatum [18]. Judul "Kucumbu Tubuh Indahku" berada pada tingkatan rheme sehingga dapat melahirkan tanda yang multitafsir, yaitu tafsir pihak yang pro yang menilai judul tersebut puitis dan tafsir pihak yang kontra yang menilai judul tersebut erotis. Representamen berupa judul film ini mendatangkan perbedaan tafsir yang kemudian melahirkan kontroversi terhadap penayangan film "Kucumbu Tubuh Indahku" yang merupakan objek atau referentnya.

\section{Referensi}

[1] Ilhamdi. Sinopsis Film Kucumbu Tubuh Indahku, Konflik Identitas Gender. Bookmyshow 2019.

[2] VIVA T. Sinopsis Kucumbu Tubuh Indahku yang Wakili Indonesia di Oscar 2020. VIVACoId \#1newstainment 2019.

[3] Lova C. Pemkot Depok Larang Film Kucumbu Tubuh Indahku Tayang di Bioskop. KompasCom 2019.

[4] Ceramah Ustadz Iqbal Siregar. Menggapai Hidayah: Fakta di Balik Film Kucumbu Tubuh Indahku 2019.

[5] News PONTV. BRITE KITE: Muda Larang Penayangan Film Kucumbu Tubuh Indahku 2019.

[6] Berita Satu. Pro-Kontra Film Garin, MUI: Sebaiknya Tak Perlu Diedarkan 2019.

[7] Fajriah N. Analisis semiotik film cin (T) a karya Sammaria Simanjuntak 2011.

[8] Sya'dian T. Analisis Semiotika Pada Film Laskar Pelangi. Proporsi J Desain, Multimed Dan Ind Kreat 2019;1:51-63.

[9] Prasetyo AT, Salsabila T, Ramadani T, Kusuma FB. Analisis Respresentasi Maskulinitas Pada Tokoh Juno Film “Ku Cumbu Tubuh Indahku.” J Syntax Transform 2020;1:531-40.

[10] Oktavia W, Indonesia TB. Semantik Ragam Makna pada Judul film'Azab 'di Indosiar. J Caraka 2019;5:133-40.

[11] Nöth W. Handbook of semiotics. Indianapolis: Indiana University Press; 1990.

[12] Yudha A, Purnomo AB, Topan MA. Teori Pendekatan Puitis Dalam Perancangan Ruang Ibadah. Pros. Semin. Nas. CENDEKIAWAN, 2019, p. 1-40.

[13] Hoed BH. Dari logika tuyul ke erotisme. IndonesiaTera; 2001.

[14] Madinah M. Analisis Tindak Tutur Ilokusi dalam Film Kucumbu Tubuh Indahku Karya Garin Nugroho 2020.

[15] Badan Pengembangan dan Pembinaan Bahasa K. Kamus Besar Bahasa Indonesia (KBBI): Kamus versi online/daring (dalam jaringan). KBBI Online 2018

[16] Aziz Z. Konstruksi Erotisme Dalam Karya Eksperimental Media Audio. Visual. J Komun 2010;2:111-27.

[17] Pradana A, Syavira F. Kucumbu Tubuh Indahku: Inspirasi peleburan seksualitas lengger lanang BBC News Indonesia 2019.

[18] Zoest A Van. Semiotika: tentang tanda, cara kerjanya dan apa yang kita lakukan dengannya. Jakarta: Yayasan Sumber Agung 1993.

[19] Seltzer L. What is autosexuality? WEEK 2019. 